\title{
Amperometric Enzyme-based Biosensors for Lowering the Interferences
}

\author{
Po-Chin Nien, Po-Yen Chen and Kuo-Chuan Ho \\ National Taiwan University \\ Taiwan
}

\section{Introduction}

\subsection{Glucose, enzymes and mediators}

Glucose becomes more and more important and popular research topics for medicine and biochemistry that monitoring biomarkers of chronic diseases, such as glucose to diabetes, bilirubin to jaundice and creatinine to kidney disease. Among many biomarkers, glucose is a common and an important biological species of human blood, found out normally in the range of about $4 \sim 8 \mathrm{mM}$. According to statistical information system of World Health Organization (WHO), the number of people with diabetes is estimated more than 180 million worldwide and it is likely to more than double by 2030. Besides, it is also estimated that $9 \%$ of all deaths worldwide are due to diabetes. Most notably, diabetes deaths are projected to increase by over 80\% in upper-middle income countries between 2006 and 2015. Therefore, it is necessary to develop an efficient glucose biosensor for monitoring the glucose level of diabetics.

Glucose is an attractive target, because it is not only an important biomarker for diabetes but also a kind of fuel for biofuel cells. In other words, the glucose biosensor can work for detecting the glucose level and for the anode of the biofuel cell. The biofuel cells were intended to power cardiac assist devices, such as artificial hearts or cardiac pacemakers (Rao \& Richter, 1974; Rao et al., 1974). For getting a good specific property, enzymes are widely applied as recognized molecules. Two kinds of enzymes with different redox potentials and electron transfer pathways are usually used to catalyze the glucose. One is the glucose oxidase (GOD) (Franke \& Deffner, 1939) from Aspergillus niger and the other is glucose dehydrogenases (GDH) from Acinetobacter calcoaceticus. For GOD catalyst, the cofactor is flavin adenine dinucleotide (FAD) with a strong bond to apo-GOD, but the cofactor can be nicotinamide adenine dinucleotide (NAD) (Boguslavsky et al., 1995), FAD (Tsujimura et al., 2006) and pyrrole quinoline quinone (PQQ) (Duine et al., 1979) for GDH. As an example, the FAD-GOD was selected in this chapter as the recognized molecule. The FAD-GOD has an apparent formal redox potential of $-0.048 \mathrm{~V}$ vs. standard hydrogen electrode (SHE) (Kulys et al., 2006) and it has a catalyzed rate of $5 \times 10^{3}$ glucose molecules per second (Willner et al., 2007a). The series catalytic mechanisms in a solution with oxygen are shown in Eqs. (1) and (2) (Warburg \& Christian, 1932).

$$
\begin{aligned}
& \text { glucose + FAD-GOD (oxidized, yellow) } \rightarrow \\
& \text { gluconic acid + FADH } 2 \text {-GOD (reduced, colorless) } \\
& \text { Source: Intelligent and Biosensors, Book edited by: Vernon S. Somerset, } \\
& \text { ISBN 978-953-7619-58-9, pp. 386, January 2010, INTECH, Croatia, downloaded from SCIYO.coM }
\end{aligned}
$$




$$
\begin{gathered}
\text { FADH } \mathrm{H}_{2} \text {-GOD (reduced, colorless) }+\mathrm{O}_{2} \rightarrow \text { FAD-GOD (oxidized, yellow) }+\mathrm{H}_{2} \mathrm{O}_{2} \\
\mathrm{H}_{2} \mathrm{O}_{2} \rightarrow 2 \mathrm{H}^{+}+\mathrm{O}_{2}+2 \mathrm{e}^{-} \\
\mathrm{H}_{2} \mathrm{O}_{2}+2 \mathrm{H}^{+}+2 \mathrm{I}^{-} \rightarrow 2 \mathrm{H}_{2} \mathrm{O}+\mathrm{I}_{2} \\
2 \mathrm{H}_{2} \mathrm{O}_{2}+4 \text {-aminoantipyrine }+ \text { phenol } \stackrel{\text { peroxidase }}{\longrightarrow} 4 \mathrm{H}_{2} \mathrm{O}+\text { quinoneimine } \\
\text { FADH }{ }_{2} \text {-GOD + mediator (oxidized) } \rightarrow \text { FAD-GOD + mediator (reduced) }
\end{gathered}
$$

The glucose concentrations can be determined indirectly by the consumption of $\mathrm{O}_{2}$ or the further reaction of $\mathrm{H}_{2} \mathrm{O}_{2}$. For example, the amperometric current can be collected by the oxidation of $\mathrm{H}_{2} \mathrm{O}_{2}$ directly (shown in Eq. (3)) (Chaubey \& Malhotra, 2002), the reaction of $\mathrm{H}_{2} \mathrm{O}_{2}$ and I- gave a I-/ $\mathrm{I}_{2}$ potentiometry (shown in Eq. (4)) (Malmstadt \& Pardue, 1961), and a spectrum change of the red dye (quinoneimine) was observed based on the reaction of Eq. (5) (Nien et al., 2008). However, the above sensing signals are sensitive to ambient oxygen concentration by any detection methods, so mediators are added into the system as shown by Eq. (6) instead of Eq. (2). The electron transfer from the redox center of $\mathrm{FADH}_{2}$ to an electrode is very sluggish and hard, because the $\mathrm{FADH}_{2}$ is embedded inside GOD by glycoprotein at a distance of about 1.3-1.5 nm (Hecht et al., 1993). The mediators not only facilitate the electron transfer from $\mathrm{FADH}_{2}$ to electrodes but also lower the sensing potential, so the choice of the mediator is very important to the sensing performance. Cyclic voltammogram is a good electro-analytical method to obtain the properties of mediators and to find suitable mediators (Gilmartin \& Hart, 1995; Nakaminami et al., 1997). The most used mediators for GOD with their formal potentials vs. standard calomel electrode (SCE) are partially listed in Table 1 (Chaubey \& Malhotra, 2002). Generally speaking, the mediators can be classified into three kinds, including organic, inorganic and metal-organic (Heller \& Feldman, 2008). In the organic mediators, methylene blue (Karyakin et al., 1993; Willner et al., 2007a; Willner et al., 2007b), quinone and its derivatives (Battaglini et al., 1994; Bourdillon et al., 1986; Cenas et al., 1983; Cosnier et al., 1998; Williams et al., 1970) have been studied for a long time. In the second kind, the main inorganic mediators are the hexacyanocomplexes of iron (Dubinin et al., 1991; Jaffari \& Turner, 1997; Shulga et al., 1994), cobalt and ruthenium, especially $\mathrm{Fe}(\mathrm{CN})_{6}{ }^{4-}$ is widely used in commercial glucose strips. In the final category, the metal-organic mediators cover ferrocene (Hendry et al., 1993; Luong et al., 1994), ferrocenemethanol (Bourdillon et al., 1995; Yang et al., 2003; Zhang et al., 2005; Zhang et al., 2006b; Zhao \& Wittstock, 2005), ferrocenecarboxylic acid (Chen et al., 2002; Kohma et al., 2007; Tian \& Zhu, 2002), Os-complex (Mano et al., 2005; Mao et al., 2003; Zakeeruddin et al., 1992) and so on. Besides, Wang et al. reported that the multi-walled carbon nanotubes

\begin{tabular}{|l|l|}
\hline Mediators & Formal potentials (mV vs. SCE) \\
\hline 1,1-dimethyl ferrocene & 100 \\
\hline ferrocene & 165 \\
\hline ferrocene carboxylic acid & 275 \\
\hline hydroxyl methyl ferrocene & 185 \\
\hline benzoquinone & 39 \\
\hline$\left[\mathrm{Fe}(\mathrm{CN})_{6}\right]^{4-}$ & 180 \\
\hline
\end{tabular}

Table 1. A partial list of the commonly used mediators for GOD. 
(MWCNTs) can disturb the secondary structure of GOD and get close to its redox center to pass the electron directly without mediators (Wang et al., 2009).

\subsection{The immobilization of enzymes and mediators}

Among various detection methods, the amperometric enzyme-based biosensor probably is the best choice for biochemical analysis due to its good selectivity, high sensitivity, rapid response, convenient measurement, miniature size, and reproducible results (Hamdi et al., 2006). In order to reuse the expensive recognized biomolecules, the enzyme has to be immobilized on the electrode. In 1972, the company of Yellow Spring Instrument in America manufactured the first commercial glucose biosensor according to the prototype of the enzyme-immobilized electrode reported by Clark and Lyons (Clark \& Lyons, 1962). In the following decades, the immobilization of enzyme became a key issue in developing the enzyme-based biosensor. Generally speaking, the immobilized methods (Cunningham, 1998) of enzyme include adsorption (Chu et al., 2007; Ekanayake et al., 2007), entrapment (Ngounou et al., 2007; Seo et al., 2007), cross-linking (Akyilmaz \& Yorganci, 2007) and covalent bonding (Lin et al., 2007a; Seo et al., 2007). For adsorption, the enzyme was attached on the electrode by the attractive force of hydrogen bonds or opposite charges, such as nylon (Gamati et al., 1991) and ion exchange resin (Zhujun \& Seitz, 1986), but it did not form a good adhesive force between biomolecules and a transducer. The enzyme also can be entrapped in a matrix, such as sol-gel (Lin et al., 2007b), Nafion® (Bogdanovskaya et al., 1997) and a conducting polymer (Brahim et al., 2001; Singh et al., 2004). The cross-linking and covalent bonding methods must be carried out by specific functional groups to link together, such as $-\mathrm{NH}_{2}$ and $-\mathrm{COOH}$ groups (Battaglini et al., 2000; Tamiya et al., 1990) or cross-linking agents (Tamiya et al., 1990). In addition, there are other methods used to immobilize the enzyme on the electrodes by thermal inkjet printing (Setti et al., 2005) or by enzyme-linked-immunosorbent-assay (ELISA) (Sehr et al., 2001). Among all methods, entrapment is considered to be one of the most attractive and popular methods to grasp the biomolecules. The electrochemical devices made by different conducting polymers entrapping recognized biomolecules have been reported extensively (Habermuller \& Schuhmann, 1998; Rahman et al., 2004; Selampinar et al., 1997), because their major advantages (Cosnier, 1999) are that polymer film can be polymerized with immobilizing enzyme in one step, and the film thickness can be controlled easily by adjusting capacity. The most common polymers used as matrixes to entrap enzyme are polyaniline (Borole et al., 2004), polythiophene, polypyrrole and its derivatives (Trojanowicz et al., 1995).

In addition to enzymes, the mediators should be immobilized in the same matrix for biosensors or biofuel cells. However, the immobilization of mediators is more difficult than that of enzyme, because the mediators usually suffer from the leakage of small molecules, water-insoluble. In the literatures reported, the covalent method is a more effective way to stabilize the mediators on the electrode. For example, the mediators were linked on the MWCNTs (Qiu et al., 2009), the polymer matrix (Himuro et al., 2009) or even the enzyme directly (Wu et al., 2008). Moreover, the mediator was linked with the electrode and the redox center of enzyme for increasing the efficiency of electron transfer from enzymes to the external circuit through mediators (Zayats et al., 2008). Qiu et al. (Qiu et al., 2007) proposed that the small molecules, mediators, were linked on the large molecules, $\mathrm{Fe}_{3} \mathrm{O}_{4} @ \mathrm{SiO}_{2}$ nanoparticles, and afterward the matrix entrapped the enzyme and the nanoparticles at the same time. 


\subsection{Challenges}

In the aspect of clinical diagnosis, the selectivity is the most major concern. For the amperometric enzyme-based biosensor which is the subject of this chapter, the challenges are how to lower the interference signals and get a precise value of glucose level in real samples. There are many oxidation-favored species in whole blood resulting in extra amperometric sensing signals, and it is a major problem of selectivity especially for electrochemical sensing.

In order to eliminate this factor, a cationic exchange membrane (Nafion ${ }^{\circledR}$ ) was the most common and easy way to put outside the electrode and this can prevent the negativelycharged interfering species, such as ascorbic acid, from reaching the surface of the electrode (Chen et al., 2009; Mailley et al., 2000; Wu et al., 2002; Zhang et al., 1994). But, the Nafion ${ }^{\circledR}$ film raised the resistance of ion-transport, in which, the response time may be increased. Another way to eliminate the interference effect is to set a pre-reaction zone on the upstream of the major sensing section. For example, L-ascorbate oxidase was immobilized in the front section of the channel (Kurita et al., 2002) to catalyze the ascorbic acid, but the other interferences passing to the electrode may still result in noises. Besides, for an electrochemical system, a new way to decrease the interferences is by means of applying different potentials for targets and interfered species. In previous study (Yuan et al., 2005), two different potentials were applied at the two working electrodes attached to scanning electrochemical microscopy (SECM) system where one was at low potential $(0.5 \mathrm{~V})$ on the substrate of glucose oxidase modified electrode and the other was at high potential $(0.7 \mathrm{~V})$ on the tip of bare platinum. Therefore, the oxidation-favored species reacted on the substrate electrode at low potential and the glucose can be catalyzed by the enzyme-modified electrode to produce hydrogen peroxide. Afterward, the $\mathrm{H}_{2} \mathrm{O}_{2}$ was oxidized again on the tip of the electrode when the gap between tip and substrate electrodes was small $(11 \mu \mathrm{m})$. Based on the similar idea, Jia et al. (Jia et al., 2008; Jia et al., 2007) proposed the probe-in-tube microdevice for eliminating the interference by the tube and detecting the target by the enzyme immobilized probe.

\section{Reviews and motivations}

In the past decade, the technique of Micro-Electro-Mechanical-Systems (MEMS) has become more and more popular for fabricating sensor chips. Due to the recent development in biotechnology, bio-MEMS is widely incorporated into the microfluidic devices in biosensors with the recognized biomolecules. The sensing chips integrate the steps of sampling, reaction, separation and detection on a chip (Richter et al., 2002). Nevertheless, they miniature the size and have the properties of fast response, less sample and low cost (Auroux et al., 2002) and this kind of sensing chip is also called Lab-on-a-chip. For example, the biosensors based on the field effect transistor (FET) made by MEMS immobilize antiPSA on the carbon nanotubes (CNTs) (Kojima et al., 2005), liquid-chromatography-based biochip detects peptide mixture (Xie et al., 2005), and the biochip combines PCR-based DNA amplification and electrochemical detection (Lee et al., 2003) have been reported. Other few examples include antibody-based chips for determining protein isoform (Loonberg \& Carlsson, 2006), liquid-chromatography-based chips for detecting peptide mixture (Xie et al., 2005), and electrophoresis-based chips for sensing catechol and dopamine (Schoning et al., 2005). Moreover, there are many choices for the materials of the microchannel, such as poly(dimethylsiloxane) (PDMS) (McDonald et al., 2000), poly(methyl-methacrylate) 
(PMMA) (Ford et al., 1998) and polycarbonate (PC) (Liu et al., 2001) ... etc. Among this, PDMS offers many advantages, including outstanding elasticity, pervious to light, good biocompatible, good mechanical stability and convenient to be fabricated, and it can be used not only for the channel stamp but also for the gas-pump (Unger et al., 2000) and gas-valve (Hosokawa \& Maeda, 2000). The PDMS stamp of channel is prepared with an air section between two layers. By filling and releasing gas to the air sections inside, the lower PDMS layer of channel can close and open the fluidic way in the micro-channel as a valve. Further, the fluid can be moved by gas-pump which is operated by three or more air sections in series filled and released continuously.

In the aspect of the electrodes on the MEMS-based biochip, the interdigitated ultramicroelectrode arrays (IDUAs) are usually used as they offer several advantages, including low ohmic drop (iR drop), high response time, enhanced sensitivity and increased signal-to-noise ratio ( $\mathrm{S} / \mathrm{N}$ ratio). The redox cycle of the species in IDUA was proposed by Bard et al. in 1986 (Bard et al., 1986). Further applications using IDUA (Fiaccabrino et al., 1998; Sheppard et al., 1996) and the search for the parameters of IDUA (Min \& Baeumner, 2004) also have been reported. Additionally, there is another new way to increase the sensitivity up to 50 times by nanopores (Muller et al., 2007). The metal-insulator-metal electrode was created with many porous caves formed by nanoparticles then etched these caves to form cylindrical holes by plasma in CF4, so the porous electrode can achieve electrochemical redox cycles in each hole vertically.

Yamato et al. (Yamato et al., 1995), firstly demonstrated that a polythiophene derivative, poly(3,4-ethylenedioxythiophene) (PEDOT), has a better long-term electrochemical stability than that of polypyrrole, and the good stability of the PEDOT was also confirmed by other researchers (Kros et al., 2005; Lerch et al., 1998). They all show that the PEDOT is a suitable material for electrochemical biosensor, so it was mainly acted as the matrix to entrap the enzyme in the studies. According to the literatures, PEDOT film not only can entrap glucose oxidase (Fabiano et al., 2002; Nien et al., 2006) or polyphenol oxidase (Vedrine et al., 2003) to fabricate a specific biosensor, but also detect single strand DNA directly (Krishnamoorthy et al., 2004).

In this chapter, two systems were reviewed to cover a good interference-independent glucose biosensor. One (system A) was designed that a three-electrode pattern was fabricated on the glass substrate by combining the technique of MEMS and covering a microchannel by the PDMS to form a sensing chip, thus the biochip worked in a flow system with the advantages of miniature, reuse, less injecting sample and continuous operation. Based on the electrochemical method, the recognized biomolecules, glucose oxidase, was immobilized by the conducting polymer, PEDOT, on the working electrode of the biochip for determining the glucose concentration. The enzyme-immobilized working electrode directly senses the catalyzed product, $\mathrm{H}_{2} \mathrm{O}_{2}$, according to Eqs. (1)-(3). Besides, a second working electrode of bare platinum, which is located in the near front of the first enzymeimmobilized working electrode, is designed for eliminating the oxidation-favored interferences near the surface of electrode before the fluid in microchannel reaching the enzyme-immobilized working electrode by applying the same potential. The schematic of the whole microfluidic sensing system, both the lateral and vertical views, is illustrated in Fig. 1.

The other (system B) is that the all-in-one electrodes, which co-immobilize with the enzymes and the mediators based on layer by layer structure shown in Fig. 2. The first layer, the 
carbon paste which was coated on the flexible substrate of stainless steel (ssteel), was acted as an adsorbent layer for the mediator, p-benzoquinone (BZQ), by the hydrophobic force. The BZQ and GOD were drop-coated on the electrode in order and the entrapped matrix, PEDOT, was electropolymerized on the outer layer to prevent the leakage of mediators and enzymes. The all-in-one electrode has the advantages of flexible, workable in oxygen-independent solution, convenient, reusable, lower sensing potential and lower interference effect.
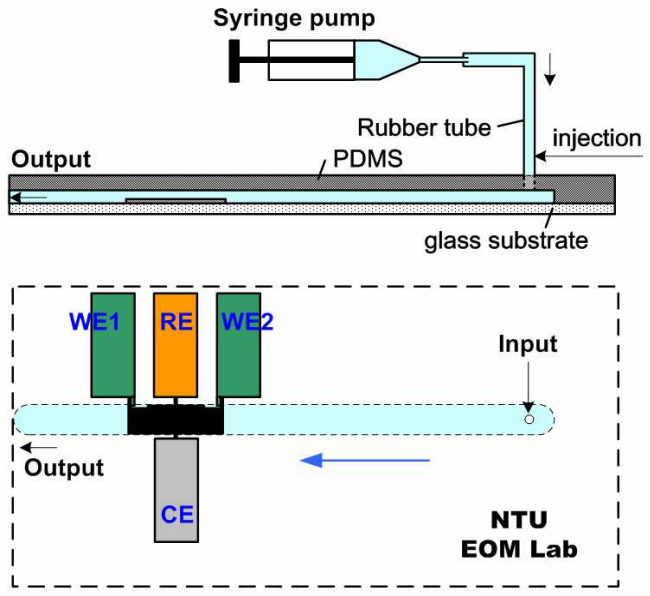

Fig. 1. The schematic of the whole system in operation for system A. (Nien et al., 2008)

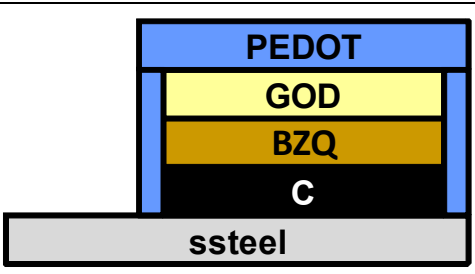

Fig. 2. The schematic of the layer by layer structure for system B.

\section{Experimental}

\subsection{Chemicals and instruments}

The target (or fuel), D-(+)-glucose, and the interferences, ascorbic acid (AA) (> 99\%), uric acid (UA) (> 99\%), dopamine hydrochloride (DA) and acetaminophen (AP) (> 99\%), were purchased from Sigma. For the enzymes, glucose oxidase (GOD) (EC 1, 1, 3, 4) type VII-S from Aspergillus niger, and laccase (Lac) (EC 1, 10, 3, 2) from Trametes versicolor were purchased from Sigma and Fluka, respectively. For the mediators, p-benzoquinone ( $\sim 98 \%$, reagent grade) 2,2-Azino-bis(3-ethylbenzothiazoline-6-sulfonic acid) (ABTS) diammonium salt were purchased from and Aldrich and Sigma, respectively. The monomer, 3,4ethylenedioxythiophene (EDOT), surfactant, polyethylene glycol (PEG, MW=20,000) and bacteriostat, sodium azide (>99.5\%) were purchased from Aldrich, Merck and Sigma, 
respectively. The phosphate buffer containing monosodium phosphate monohydrate, disodium phosphate heptahydrate and potassium chloride (99.0 100.5\%), were all purchased from Sigma. Besides, in system A, the positive photoresist, FH-6400, and the developer, FHD-5, were purchased from Fujifilm. The pre-polymer PDMS (Sylgard 184) and curing agent were from Dow Corning. The photolithographic equipments in clean-room are following: UV mask aligner (EVG 620) and inductively coupled plasma-reactive ion etching (ICP-RIE). The solution in the channel was pumped by a syringe pump (KdScientific, model 100). In system B, the flexible substrate was stainless steel SUS 301 and the membrane for biofuel cell was Nafion ${ }^{\circledR} 117$ (thickness is 0.007 in). The de-ionized water (DIW) was used throughout the experiments. All electrochemical experiments, including CV and amperometric measurements were performed with a potentiostat/galvanostat (CHI 440 and CHI 900).

\subsection{Fabrication of system $A$}

First, the film mask with a resolution of 10,000 dpi was made by Taiwan Kong King Company according to the self-designed electrode shown in Fig. 3. All of the following steps were done by silicon planar technology in a clean-room environment. The glass wafer with a diameter of 4 in and a thickness of $1 \mathrm{~mm}$ was cleaned by acetone, water and $\mathrm{N}_{2}$-purge orderly. For enhancing the adhesive force between photoresist and glass wafer, the wafer was coated with hexamethyldisilazane (HMDS) in advance by vapor priming. Then the glass wafer was covered with chemical positive photoresist (FH-6400) by spin-coating at $1,500 \mathrm{rpm}$ for $30 \mathrm{~s}$ and hardened at $90{ }^{\circ} \mathrm{C}$ for $90 \mathrm{~s}$ on a hot plate. After soft baking, the wafer was selectively exposed through a UV mask aligner to UV light $\left(12 \mathrm{~s}, 10 \mathrm{~mJ} / \mathrm{cm}^{2}\right)$ with the first mask, and removed photoresist in the developer soup (FHD-5) for $12 \mathrm{~s}$ to form the pattern of the reference electrode. For the reference electrode, the metal layers of $\mathrm{Cr}, \mathrm{Au}$ and Ag were deposited by sputtering in order, and the thicknesses of those are about 30, 90 and $360 \mathrm{~nm}$, respectively. The layers of $\mathrm{Cr}$ and $\mathrm{Au}$ are served as buffer layers to enhance the adhesive force of silver on glass. The unnecessary metal layers were lifted off completely in the acetone solution by ultrasonic method. In the same process, the patterns of working and counter electrodes with the metal layers, $30 \mathrm{~nm} \mathrm{Cr}$ and $100 \mathrm{~nm} \mathrm{Pt}$, were fabricated by the second mask. The working and counter electrodes are the designation of IDA with the same width $(50 \mu \mathrm{m})$ of fingers and gaps, as shown in the insert of Fig. 3. The real geometric surface areas of working, counter, and reference electrode are 4.5, 9.75 and $1.3 \mathrm{~mm}^{2}$ respectively.

The channel stamp was made by PDMS according to the mother mold of the silicon wafer. First, the silicon substrates were washed with acetone and sulfuric acid to remove any organic contaminants. All the substrates were then dried under a $\mathrm{N}_{2}$ stream and used immediately after cleaning. Silicon wafers were coated with a $2 \mu \mathrm{m}$ thick positive photoresist (FH-6400) by using a spin coater. They were pre-baked on a hot plate with a temperature of $90{ }^{\circ} \mathrm{C}$ for $90 \mathrm{~s}$. The light exposure was followed for $12 \mathrm{~s}$ and developed for 12 s. Finally, silicon wafer was dry-etched by ICP-RIE for $100 \mu \mathrm{m}$ deep and the patterns were transferred to the silicon mold. A fully mixed viscous precursor of PDMS and curing agent in the ratio of 10:1, was poured into the silicon master, pumped in a vacuum for a period of time to remove all bubbles, and then thermally cured at $60{ }^{\circ} \mathrm{C}$ in an oven for $3 \mathrm{hrs}$. After curing, the PDMS stamp could be peeled off from the silicon master. Finally, the PDMS and the glass wafer were bombarded by oxygen plasma at $50 \mathrm{~W}$ for $3 \mathrm{~min}$ to modify their 
functional groups of surfaces from hydrophobic to hydrophilic temporarily. Then the channel of the PDMS was covered and glued on the glass to form a sensor chip.

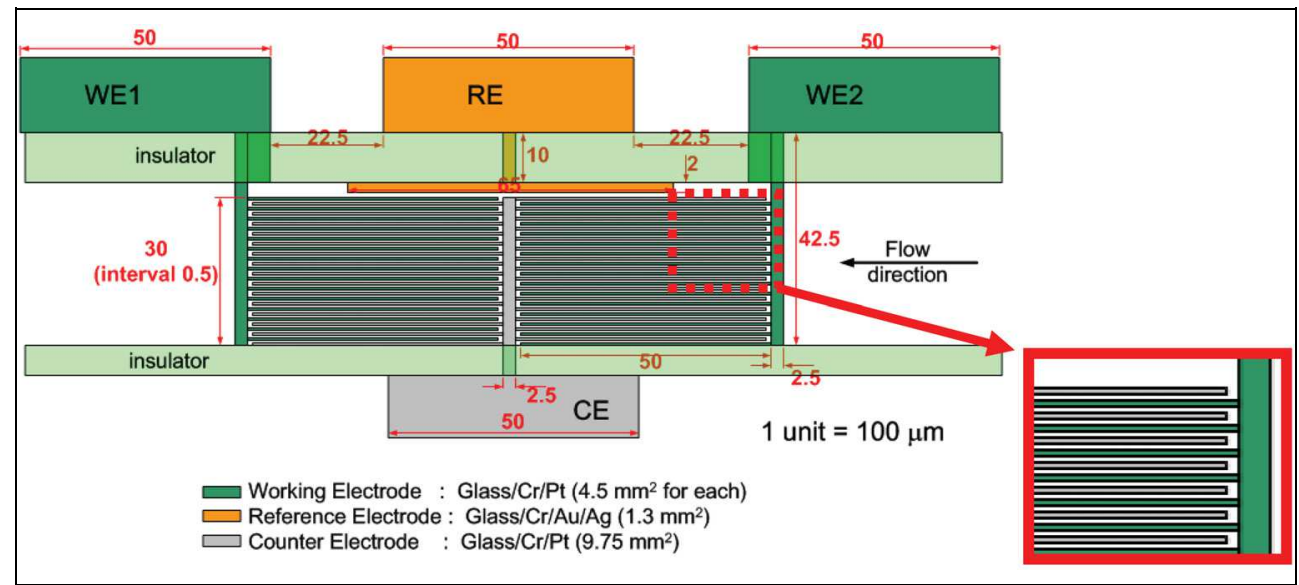

Fig. 3. The schematic of the microelectrode.

For the purpose of getting a more stable reference, the silver surface of reference electrode was modified to $\mathrm{Ag} / \mathrm{AgCl}$ by chemical deposition. According to Eq. (7), the Ag surface was oxidized to form a thin layer of $\mathrm{AgCl}$ in $0.1 \mathrm{M} \mathrm{FeCl}_{3}$ solution spontaneously for $1 \mathrm{hr}$. For the enzyme-modified working electrode, the conducting polymer, PEDOT, was prepared in a flow system and the other conditions are the same as described in our previous work (Nien et al., 2006). The PEDOT film was obtained by electropolymerization of EDOT with the sweeping potential from 0.2 to $1.2 \mathrm{~V}$ for 20 cycles at a flow rate of $5 \mathrm{ml} / \mathrm{hr}$ and it was used as a matrix to entrap the glucose oxidase for immobilization on "WE1" (in Fig. 3) in a $0.02 \mathrm{M}$ PBS electrolyte containing 2,000 $\mathrm{U} / \mathrm{ml}$ glucose oxidase and $0.3 \mathrm{M} \mathrm{KCl}$. After electropolymerization, the $0.02 \mathrm{M}$ PBS solution was allowed to flow in the channel for some time to wash out the residuals. The sensing chip was stored at $4{ }^{\circ} \mathrm{C}$ when not use.

$$
\mathrm{Ag}+\mathrm{Cl}^{-}+\mathrm{Fe}^{3+} \rightarrow \mathrm{AgCl}+\mathrm{Fe}^{2+} \quad \mathrm{E}^{0} \text { reaction }=0.55 \mathrm{~V}
$$

\subsection{Fabrication of system B}

The substrate, ssteel, was cleaned in the alcohol and water by supersonic wave to remove the organic matter. Then the carbon paste was roll coated on the substrate with constant spacer and area of $1 \times 1 \mathrm{~cm}^{2}$, which is a large area comparing to literatures, and thermally cured in the oven at $130{ }^{\circ} \mathrm{C}$ for $2 \mathrm{hr}$ to remove solvent. Afterward, the mediator, BZQ (50 $\mathrm{mM}$ ) dissolved in dimethylformamide (DMF), and the GOD dissolved in water $(5000 \mathrm{U} / \mathrm{ml})$ were both dropped a volume of $40 \mu \mathrm{l}$ on the ssteel/C electrode to dry in order. At last, the conducting polymer, PEDOT was electropolymerized on the outer layer of the prepared ssteel/C/BZQ-GOD electrode to prevent the leakage of GOD, in a $\mathrm{pH} 7$ phosphate buffer solution containing $10 \mathrm{mM}$ EDOT monomer and $0.1 \mathrm{mM}$ non-ionic surfactant, PEG, by applying a constant potential of $1.2 \mathrm{~V}$ vs. $\mathrm{Ag} / \mathrm{AgCl} / \mathrm{sat}^{\prime} \mathrm{d} \mathrm{KCl}$ for $50 \mathrm{~s}$. Afterward, the ssteel/C/BZQ-GOD/PEDOT electrode was stored in a $\mathrm{pH} 7 \mathrm{PBS}$ at $4{ }^{\circ} \mathrm{C}$ when not in use. 


\section{Results and discussions of system $A$}

\subsection{The sensing chip}

In each 4-in glass wafer, two pieces of sensing chips $(70 \mathrm{~mm} \times 35 \mathrm{~mm})$ were cut by a diamond cutter. The microelectrode arrays can be divided into four sections (mentioned in section 3.2) and the surface metal layer of the working, reference and counter electrodes are platinum, silver and platinum, respectively. The SEM pictures (not shown) indicated that the dimension of the interdigitated array was the same as that of the designed pattern. Finally, by covering the PDMS with a microfluidic channel of $100 \mu \mathrm{m}$ height, the sensing chip was fabricated. Moreover, for getting a better stability of long-term operation, the surface of reference electrode was modified as $\mathrm{Ag} / \mathrm{AgCl}$ by chemical deposition. The open circuit voltage $\left(\mathrm{V}_{\mathrm{oc}}\right)$ of the $\mathrm{Ag} / \mathrm{AgCl}$ is about $95 \mathrm{mV}$ vs. SCE (commercial model) in the electrolyte of $0.3 \mathrm{M} \mathrm{KCl}$ and the variation between the two electrodes is less than $5 \mathrm{mV}$ for a period of 2,500 s. It was approximately corresponding to the theoretical value of $102.9 \mathrm{mV}$ based on the electrochemical theory.

When the potential of the first working electrode (WE1) was cycled between a potential range of $0.2 \sim 1.2 \mathrm{~V}$ at a scan rate of $0.1 \mathrm{~V} / \mathrm{s}$, the current for the first cycle increased at around $0.7 \mathrm{~V}$ due to the oxidation of the EDOT monomer. On electrooxidation, a radical cation of EDOT is produced which is transformed to a polymeric species via several followup reactions. However, the anodic current at higher potential $(0.9-1.2 \mathrm{~V})$ decreased with the cycle number, because the high potential may result in the partial degradation (Fabiano et al., 2002) or overoxidation of PEDOT film. In the $15^{\text {th }}$ to $20^{\text {th }}$ cycles, the CVs of polymerization were almost the same and this implies that the polymer film was not growing due to the resistance of polymer film. During the polymerization process, the PEDOT possesses positive charges, so the negatively charged glucose oxidase ( $\mathrm{pI}=4.2)$ would migrate to the PEDOT surface at $\mathrm{pH}=7.4$ (PBS) and be grabbed by the growing polymer chains. Besides, it is also an advantage of $\mathrm{CV}$ method that the enzyme has more time to diffuse to the polymer surface when the applied potential was swept to the cathodic direction in which the EDOT can't be polymerized. The immobilized enzyme was quantified as about $0.101 \mathrm{U} / \mathrm{cm}^{2}$ by UV spectrophotometer after series chemical reactions in previous work (Nien et al., 2008).

\subsection{The sensing performance}

In Fig. 4, the flow injection data were obtained by applying $0.7 \mathrm{~V}$ at a flow rate of $10 \mathrm{ml} / \mathrm{hr}$ and each current pulse was resulted from different concentrations with an injecting volume of $30 \mu \mathrm{l}$. Besides, both the peak current and the charge capacity of each pulse can be collected as the sensing signal. However, the reproducibility in the peak currents was not good and hence the charge capacities were used for recording the sensing signal instead of current. The relationship obtained between the net charge capacities and the different glucose concentrations by applying a voltage of $0.7 \mathrm{~V}$ vs. $\mathrm{Ag} / \mathrm{AgCl}$ on PEDOT modified enzyme electrode (WE1) with the same injecting volume of $30 \mu \mathrm{l}$ at different flow rates is shown in Fig. 5. The linear regression falls from 1 to $10 \mathrm{mM}$, which includes the range of normal human blood, with a sensitivity of $157 \mu \mathrm{C} \mathrm{cm}^{-2} \mathrm{mM}^{-1}\left(4.6 \mu \mathrm{A} \mathrm{cm}^{-2} \mathrm{mM}^{-1}\right.$ in current plot, which is not shown). The sampling time, the time taken from each injection of the sample to the pulse current returning approximately to the background level, was within $180,100,70$ and $30 \mathrm{~s}$ at a flow rate of 5, 10, 20 and $50 \mathrm{ml} / \mathrm{hr}$, respectively. Operating at a high flow rate had a faster response, but lost another important parameter, sensitivity. Hence the 


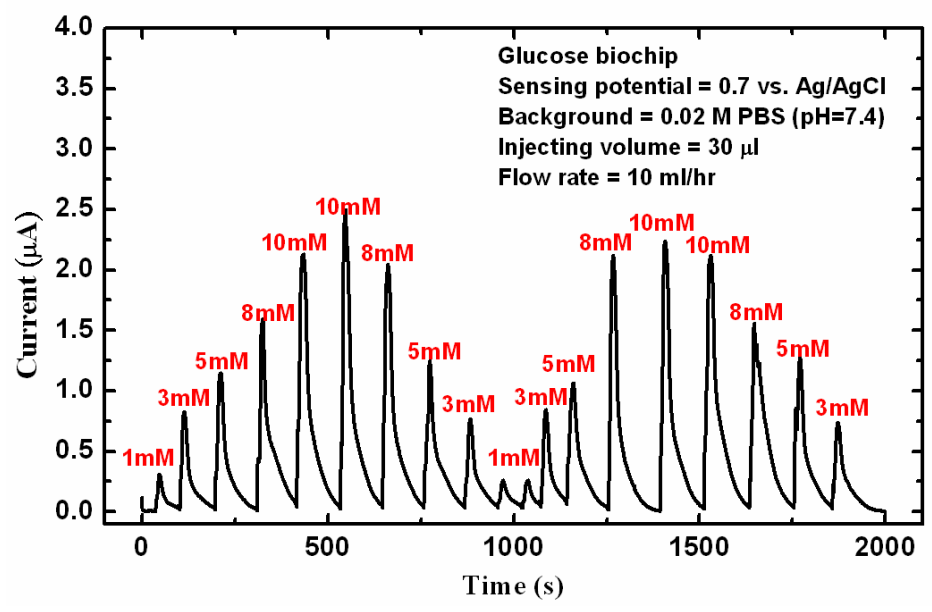

Fig. 4. The sensing signals of the biosensor in response to various glucose concentrations using flow injection analysis.

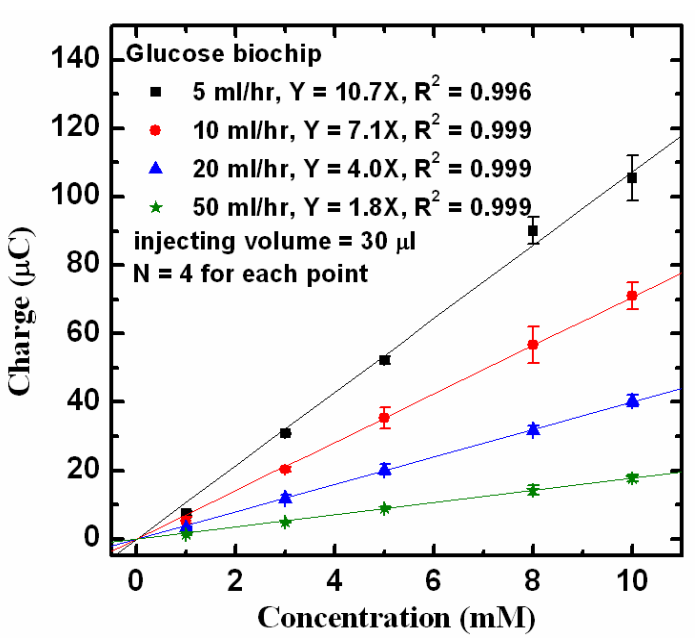

Fig. 5. The calibration curve based on charge at different flow rates.

proper flow rate was selected as $10 \mathrm{ml} / \mathrm{hr}$ by considering the performance. The response time and the recovery time, defined as the time taken for the current reaching of $95 \%$ of the steady-state level, are about $15 \mathrm{~s}$ and $35-75 \mathrm{~s}$, respectively. For different concentrations of the samples, the response time is almost the same, but the recovery time varies with the concentration. The higher concentration of sample leads to longer recovery time, since the larger driving force of mass transport results in a broader concentration profile. Additionally, the limit of detection (LOD) based on signal to noise ratio equaling to 3 is 0.15 $\mathrm{mM}$ at $10 \mathrm{ml} / \mathrm{hr}$. 
Table 2 is a partial list of the amperometric GOD-based glucose sensors, obtained from the literatures based on PDMS chips. They used capillary electrophoresis to separate the interferences (Liu et al., 2006; Zhang et al., 2006a) and immobilized lactate oxidase to catalyst the ascorbic acid on the upstream (Kurita et al., 2002). Besides, the sensing chip (Huang et al., 2007) can not only detect glucose concentrations but also inject insulin automatically. In the aspect of sensing performance, the linear ranges almost covered the normal human range (3.5-8 $\mathrm{mM})$, but system A provided fast response and recovery times. However, the limit of the detection was not as low as the others, and hence the applications may have some limitations.

\begin{tabular}{|c|c|c|c|c|c|c|}
\hline References & $\begin{array}{c}\text { Immobilized } \\
\text { method }\end{array}$ & $\begin{array}{c}\text { Sensitivity } \\
\left(\mu \mathrm{A} \mathrm{cm}^{-2}\right. \\
\left.\mathrm{mM}^{-1}\right)\end{array}$ & $\begin{array}{c}\text { Linear } \\
\text { range } \\
(\mathrm{mM})\end{array}$ & $\begin{array}{c}\text { Response } \\
\text { time }(\mathrm{s})\end{array}$ & $\begin{array}{c}\text { Recovery } \\
\text { time }(\mathrm{s})\end{array}$ & $\begin{array}{c}\mathrm{LOD} \\
(\mathrm{\mu M})\end{array}$ \\
\hline (Zhang et al., 2006a) & adsorption & --- & $0-30$ & 10 & 15 & 6.5 \\
\hline (Liu et al., 2006) & adsorption & 0.0312 & $0.01-5$ & --- & --- & 5 \\
\hline (Yamaguchi et al., 2002) & entrapment & 8.67 & $0-20$ & 50 & --- & - \\
\hline (Kurita et al., 2002) & entrapment & 0.0025 & $0.01-1$ & 120 & --- & 2.3 \\
\hline (Huang et al., 2007) & entrapment & 0.0076 & $2-30$ & 50 & --- & --- \\
\hline System A & entrapment & 4.6 & $1-10$ & 15 & $35-75$ & 150 \\
\hline
\end{tabular}

Table 2. Partial literatures of the amperometric GOD-based glucose sensors on PDMS chips.

\subsection{The interferences effect and the monitoring of real sample}

One of the most important problems to tackle for any practical application of amperometric biosensors is to minimize the effect of interfering substances possibly present in a real sample. For oxidase-based systems, reductants are the most severe interferences and among these ascorbate and uric acid (Navera et al., 1993; Vasantha \& Chen, 2006) are two of the most considered. Moreover, well-separated voltammetric peaks were observed for dopamine and ascorbate anion at the PEDOT modified electrodes at 0.21 and $0.08 \mathrm{~V}$, respectively (Matuszewski et al., 1990). Although the linear range covers the glucose level of normal human, the oxidation-favored interferences in blood, such as ascorbic acid (AA) and uric acid (UA), still raise the sensing currents at a high voltage of $0.7 \mathrm{~V}$. To solve this, the pre-reaction section, "WE2" in Fig. 3, was designed to reduce the interference effect in this microsystem. Here, the bi-potential was applied simultaneously to both WE1 and WE2 by the bi-potentiostat of $\mathrm{CHI}$ 900. In the flow injecting analysis, when the samples were injected, the oxidation-favored substances near the boundary layer were oxidized at $0.7 \mathrm{~V}$ (vs. $\mathrm{Ag} / \mathrm{AgCl}$ ) on WE2. Consequently, the interferences near the boundary layer were partially eliminated to some extent before the analyte arriving to WE1. The electrode gap between WE1 and WE2 $(0.25 \mathrm{~mm})$ is designed to be very close so as to avoid the solution diffusing from the outside boundary layer into the inside layer. For a single-potential test on WE1, both $0.08 \mathrm{mM}$ AA sample and a blend of $0.08 \mathrm{mM}$ AA plus $10 \mathrm{mM}$ glucose sample reached $31.3 \%$ and $145.5 \%$ of the sensing current obtained for $10 \mathrm{mM}$ glucose, respectively. AA contributes a significant current to the total current on the PEDOT enzyme-modified electrode. In contrast, the sensing current of the blend sample reached $99.6 \%$ that of $10 \mathrm{mM}$ glucose response in a bi-potential test. The result shows that the concentration of the oxidation-favored species in the sample was reduced appreciably. Therefore, it is concluded that the bi-potential configuration can reduce the interferences in a flow injection system 
and thereby improving the selectivity and specificity of an enzyme modified electrode towards glucose oxidation.

For the real sample test, three different methods were used to monitor the glucose concentration of the human blood. One was determined by a hospital, another was obtained by a handheld commercial product (EasiCheck blood glucose test strips) and the third was detected by this sensing chip. After the oxidation of the interferences on WE2, the reduced concentration of the interferences in the boundary layer can enhance the accuracy of glucose sensing for WE1. The results obtained from the three methods are shown in Table 3 and the percentages of the detecting error were calculated according to the value obtained from hospital as a standard. Moreover, the bias of the bi-potential $(+13.6 \%)$ was much lesser than that of single-potential $(+141 \%)$, and this confirms that the WE2 helps to eliminate the interference. For the commercial product, the average concentration of three tests was 4.77 $\mathrm{mM}$ and the bias was about $+5 \%$ which is within the bias range $( \pm 20 \%)$ of the product prescription. Although the error of the bi-potential was acceptable grudgingly, it may be lowered further by increasing the active area of WE2.

\begin{tabular}{|c|c|c|}
\hline Glucose biochip & Commercial product & NTU Hospital \\
\cline { 1 - 1 } $\begin{array}{c}\text { Single-potential }=10.99 \mathrm{mM} \\
\text { (Bias }=+141 \%)\end{array}$ & $\begin{array}{c}4.77 \mathrm{mM} \\
\text { (Bias }=+4.6 \%)\end{array}$ & $\begin{array}{c}4.56 \mathrm{mM} \\
\text { (as a standard) }\end{array}$ \\
\cline { 1 - 2 } $\begin{array}{c}\text { Bi-potential }=5.18 \mathrm{mM} \\
\text { (Bias }=+13.6 \%)\end{array}$ & & \\
\hline
\end{tabular}

Table 3. A summary of the detecting errors for a real sample tested against different methods.

\section{Results and discussion of system $B$}

\subsection{The enzyme electrode}

For the stable test of BZQ adsorbed inside the electrodes, it was under the sweeping potentials between -0.6 and $0.8 \mathrm{~V}$ for 100 cycles. With increasing cycle numbers, the peak currents of redox reaction were decreased to stable values after about 50 cycles (not shown). This implied that the electrodes can reach to a stable situation after the leakage of the weakly-adhesive BZQ. It showed that the first layer, carbon, was a good substrate for the adsorption of BZQ. For the third layer, the GOD dry-coated on the electrode may dissolve into the electrolyte while the step of electropolymerization. As a result, the immobilized amount of GOD can be quantified by the absorbance change of the electrolyte before and after polymerization. According to the UV spectrum (not shown) of the electrolyte at 280 $\mathrm{nm}$, which is the maximum absorbent wavenumber for GOD, the leakage of GOD in the electrolyte was calculated to be about $132 \mathrm{U}$ and the entrapped efficiency was about $33 \%$ for the electrode B. The immobilized amount of GOD by this method is about $68 \mathrm{U} / \mathrm{cm}^{2}$ which is higher than $0.101 \mathrm{U} / \mathrm{cm}^{2}$ of the GC electrode by entrapping enzyme and polymerizing PEDOT at the same time reported in the previous work (Nien et al., 2006).

\subsection{The sensing performance}

For glucose biosensors, the prepared electrode worked in the nitrogen purged glucose solutions at a stiring rate of $100 \mathrm{rpm}$ by applying a sensing potential of $0.3 \mathrm{~V}$ to record the oxidation sensing current of BZQ. The calibration curve of the electrode was shown in Fig. 6 
and the sensitivity was $2.21 \mathrm{~mA} \mathrm{M}^{-1} \mathrm{~cm}^{-2}$ with a $\mathrm{R}^{2}$ value of 0.993 . Besides, the other performances including linear range, response time and limit of detection were 1.1-15 $\mathrm{mM}$ (human range included), 95-105 $\mathrm{s}$ and $1.1 \mathrm{mM}$, respectively. Comparing to the previous works of co-immobilization of GOD and mediators, the sensitivity is better than 0.79 (Himuro et al., 2009), 0.111 (Crespilho et al., 2008) and 1.86 (Qiu et al., 2007) $\mathrm{mA} \mathrm{M}^{-1} \mathrm{~cm}^{-2}$ In the first work, the GOD was linked on the mediator-based copolymer backbone, poly(vinylferrocene-co-2-hydroxyethyl methacrylate), and polyamidoamine particle linked by GOD was co-immobilized with the gold nanoparticles modified by cobalt hexacyanoferrate (mediator) on conducting glass in the second work. In the last work, the GOD and ferrocene monocarboxylic acid-modified $\mathrm{Fe}_{3} \mathrm{O}_{4}$ nanoparticles were both entrapped on carbon paste electrode. In addition, only the linear range of the first literature (1.4-8.9 $\mathrm{mM})$ covered the normal human range.

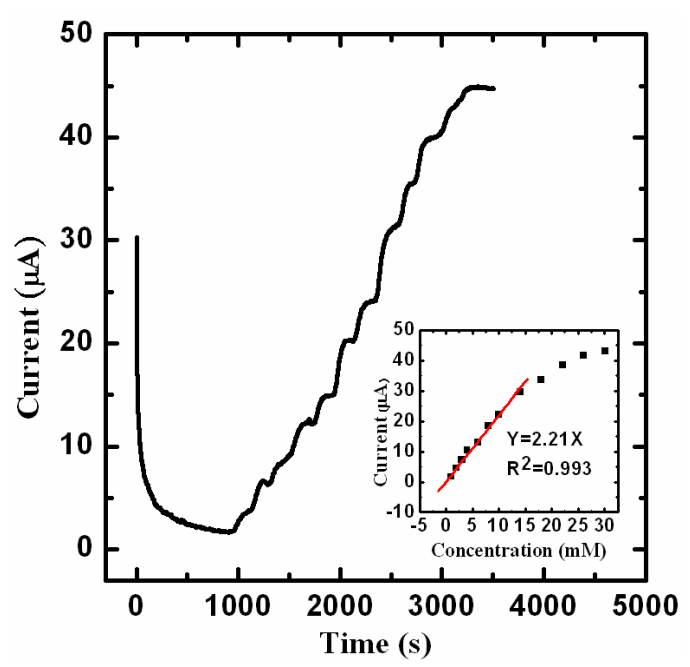

Fig. 6 . The current response with increasing glucose concentrations and the calibration curve (inset) for system B.

\subsection{The interferences effect and monitoring of real sample}

For simulating the real sample, the most common interferences including AA, DA, UA and $\mathrm{AP}$ were applied in this system, and their formal potentials are about $0.2 \mathrm{~V}, 0.3 \mathrm{~V}, 0.5 \mathrm{~V}$ and $0.3 \mathrm{~V}$ vs. $\mathrm{Ag} / \mathrm{AgCl} / \mathrm{sat}^{\prime} \mathrm{d} \mathrm{KCl}$, respectively. Besides, the normal ranges of those four species in blood are $34-80 \mu \mathrm{M},<1 \mu \mathrm{M}, 178-416 \mu \mathrm{M}$ and $130-150 \mu \mathrm{M}$, respectively. The current responses of the interferences were shown in Fig. 7 based on the sensing current of $6 \mathrm{mM}$ glucose as $100 \%$. In Fig. 7, there is almost no current response for UA owing to the insufficient overpotential. However, the sensing current of DA was higher than that of AA which has a lower oxidized potential. It is because some carbons on the polymer backbone was over-oxidized and transformed into carboxylic groups at a high potential when polymerization (Cosnier, 2003; Vidal et al., 2001). In the literature (Palmisano et al., 1995), the carboxylic groups on the over-oxidized conducting polymer, polypyrrole, were proved by X-ray photoelectron spectroscopy (XPS). In other words, the charge of PEDOT polymer 
chain changed to partial negative from positive, so the PEDOT film preferred to attract positive DA ( $\mathrm{pK}=8.87$ ) than negative AA ( $\mathrm{pK}=4.1)$ in the PBS of $\mathrm{pH}$ 7. Additionally, the AP with positive charge resulted in 3\% current response owing to the same way stated above. Finally, the whole blood from human beings was also monitored in a batch system and it shows an bias of $+3.6 \%$ according to the standard glucose concentration of $4.94 \mathrm{mM}$ obtained from National Taiwan University Hospital. As a result, the modified electrode presents a good performance for real samples detections in an oxygen-independent system.

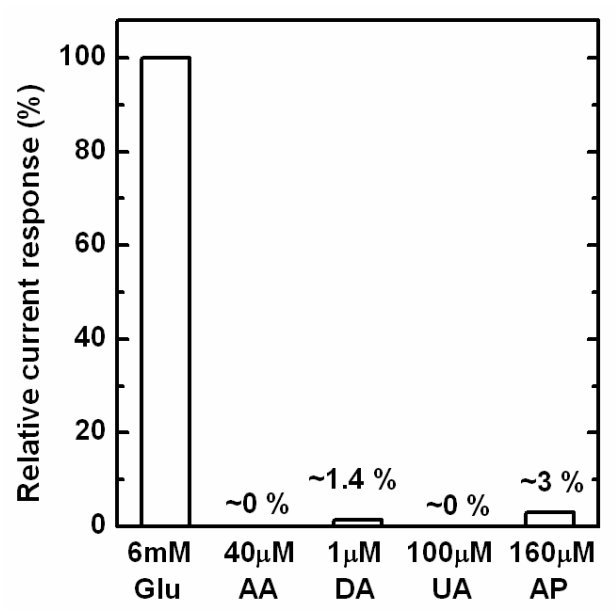

Fig. 7. The relative current response of the common interferences in human blood.

\subsection{The application of biofuel cell}

The modified electrode was employed for not only as a glucose biosensor but also as an anode for biofuel cell. In the following biofuel cell system proposed, the anode was the modified electrode immobilized BZQ and GOD, and the cathode was the platinum electrode in the ABTS and Lac solution. Figure 8 shows the I-V curves obtained by sweeping potentials from open circuit voltage $\left(\mathrm{V}_{\text {oc }}\right)$ to $0 \mathrm{~V}$ and power curves in $0 \mathrm{M}$ and $0.1 \mathrm{M}$ glucose solution at room temperature and body temperature, which means $25{ }^{\circ} \mathrm{C}$ and $37{ }^{\circ} \mathrm{C}$, respectively. In the Fig. 8A, the $\mathrm{V}_{\text {oc }}$ increased to $0.6 \mathrm{~V}$ from $0.52 \mathrm{~V}$ and the cell current had an obvious enhancement after adding $0.1 \mathrm{M}$ glucose. It implied that the glucose biofuel cell was workable and sensitive to glucose concentration. Based on Fig. 8A, the power curves shown in Fig. $8 \mathrm{~B}$ can be calculated from the current multiplied by cell voltage. In Fig. 8B, the cell power of the $0 \mathrm{M}$ glucose solution was $7 \mu \mathrm{W} / \mathrm{cm}^{2}$ and the cell acted as a non-regenerated cell by the redox reactions of the mediators in each compartments. Besides, the maximum power of $22.5 \mu \mathrm{W} / \mathrm{cm}^{2}$ (at $\mathrm{V}_{\text {cell }}=0.235 \mathrm{~V}$ and $\mathrm{I}=95.8 \mu \mathrm{A}$ ) at body temperature was slightly higher than that of $18.9 \mu \mathrm{W} / \mathrm{cm}^{2}$ (at $\mathrm{V}_{\text {cell }}=0.212 \mathrm{~V}$ and $\left.\mathrm{I}=89.1 \mu \mathrm{A}\right)$ at room temperature. It is because the power at $37{ }^{\circ} \mathrm{C}$ is affected by the higher catalytic activity of enzyme and the lower fuel solubility of oxygen in cathode.

In this system, the anode was assigned as the rate-determining electrode to optimize the amount of BZQ and GOD. Thus, the catholyte always contains sufficient ABTS and Lac comparing to anodic electrolyte and the maximum reaction rate of cathode was much higher 


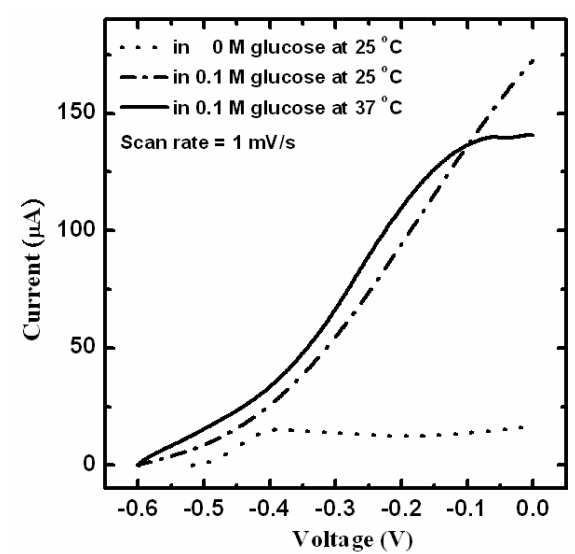

(A)

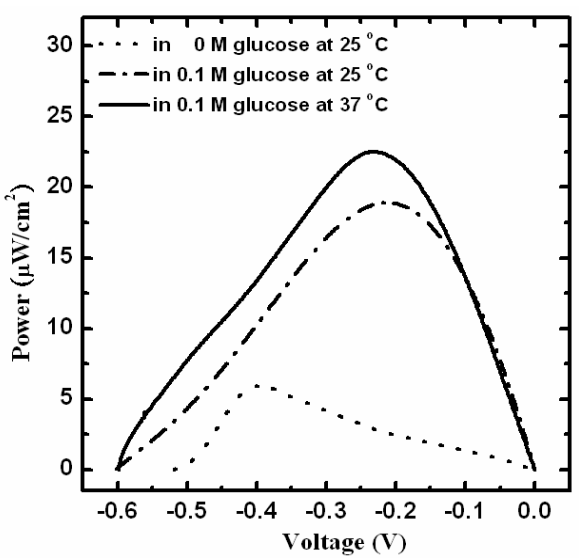

(B)

Fig. 8. (A) The I-V curve and (B) the power curve of the biofuel cell at $25^{\circ} \mathrm{C}$ and $37{ }^{\circ} \mathrm{C}$.

than that of anode. Figure 9 shows the maximum powers of the cell with the anodes prepared by different amounts of BZQ and GOD at $25^{\circ} \mathrm{C}$. The maximum powers were only varied with the amount of BZQ but GOD in Fig. 9. However, the immobilized content of BZQ was much high according to its redox peak current, and the mole ratio of that to the quantitative GOD (mole of BZQ/mole of GOD) was much larger than 10. It may be due to the poor contact between the BZQ with hydrophobic property and GOD with hydrophilic property. In other words, the electron-transfer reaction may be only carried out in the nearinterface of BZQ and GOD layers, so it also resulted in lower sensing current and cell power. Besides, the powers of the electrode prepared by $80 \mu \mathrm{l} B \mathrm{BQ}$ were almost the same as that by $40 \mu \mathrm{lBZQ}$, so the optimal condition was $40 \mu \mathrm{l} \mathrm{BZQ}$ and GOD.

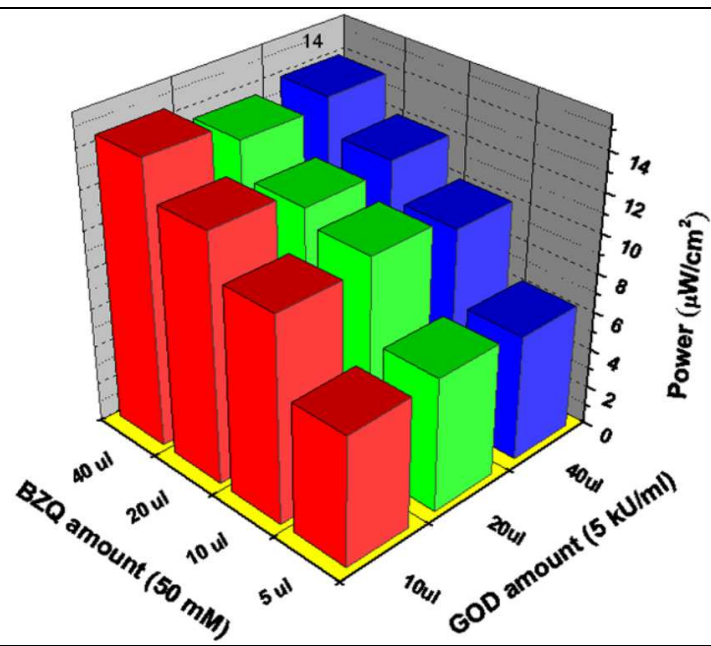

Fig. 9. The maximum cell powers using different anodes prepared by various amounts of BZQ and GOD at $25^{\circ} \mathrm{C}$ 
Table 4 shows a partial list of the literatures for the biofuel cells immobilized GOD and Lac by physical immobilized methods, such as adsorption and entrapment. In the first three references (Nos. 1-3), the cells with the mediators dissolved in electrolytes were carried out in membrane systems. However, the mediators were immobilized on the electrodes for the last two references (Nos. 4-5). According to Table 4, this system can provide a largest $\mathrm{V}_{\mathrm{oc}}$ and the maximum power is better than that of some references (Nos. 1, 3, 4).

\begin{tabular}{|c|c|c|c|c|c|}
\hline \multirow{2}{*}{ No. } & \multirow{2}{*}{ Reference } & Immobilized & \multicolumn{2}{|c|}{$\begin{array}{l}\mathrm{V}_{\mathrm{oc}} \\
\text { Method }\end{array}$} & \multicolumn{2}{|c|}{ Power $\left(\mathrm{VW} / \mathrm{cm}^{2}\right)$} \\
\cline { 5 - 6 } & & & $23{ }^{\circ} \mathrm{C}$ & $37{ }^{\circ} \mathrm{C}$ \\
\hline 1 & (Yan et al., 2007) & Lipid based & 0.45 & 3.2 & --- \\
\hline 2 & (Liu \& Dong, 2007a) & Gel & 0.4 & 29 & --- \\
\hline 3 & (Liu \& Dong, 2007b) & Gel & 0.25 & 10 & --- \\
\hline 4 & (Habrioux et al., 2007) & Adsorption & 0.3 & --- & 16 \\
\hline 5 & (Brunel et al., 2007) & Adsorption & 0.3 & --- & 29 \\
\hline 6 & System B (Nien et al., 2009) & Entrapment & 0.6 & 18.9 & 22.5 \\
\hline
\end{tabular}

Table 4. A partial list of literatures on the power output of biofuel cells with glucose oxidase and laccase which were immobilized by adsorption and entrapment.

\section{Conclusions and future works}

In system A, the PEDOT-modified electrode was used as a matrix to entrap glucose oxidase and was integrated in a flow system of sensing chip successfully. The optimal injecting volume and flow rate were $30 \mu \mathrm{l}$ and $10 \mathrm{ml} / \mathrm{hr}$, respectively. The performances of sensitivity, linear range, response time, recovery time and limit of detection were $157 \mu \mathrm{C} \mathrm{cm}^{-2} \mathrm{mM}^{-1}, 1-10 \mathrm{mM}, 15 \mathrm{~s}, 35-75 \mathrm{~s}$ and $0.15 \mathrm{mM}$ at a flow rate of $10 \mathrm{ml} / \mathrm{hr}$, respectively. With an applied potential of $0.7 \mathrm{~V}$ on WE2, it can reduce the interference current of WE1. Since the interferences in the flow channel near the surface of the first electrode (WE2) had been pre-reacted electrochemically, and the interference-free sensor can be achieved at the second electrode (WE1). In the real sample test, the bias of bi-potential was $+13.6 \%$, which is lower than that of single-potential. In system B, the proposed electrode fabricated by multilayer structures successfully works as a glucose biosensor in the oxygen-independence solution, and the anode of the biofuel cell by adding not only glucose solution but also the real blood of human beings. The electrode prepared by BZQ/DMF, shows a sensitivity of $2.21 \mathrm{~mA} \mathrm{M}^{-1} \mathrm{~cm}^{-2}$, a linear concentration range of 1.1 15 $\mathrm{mM}$ (including the human blood range) and a response time of $100 \mathrm{~s}$ at a sensing potential of $0.3 \mathrm{~V}$. Besides, the current responses of the common interferences in blood were much lower than that of $6 \mathrm{mM}$ glucose because of the low sensing potential and the patially negative charged polymer film. As the glucose $/ \mathrm{O}_{2}$ biofuel cell, the $\mathrm{V}_{\mathrm{oc}}$ can reach to $0.6 \mathrm{~V}$ and the maximum power was $22.5 \mu \mathrm{W} / \mathrm{cm}^{2}$ at $37{ }^{\circ} \mathrm{C}$ in $0.1 \mathrm{M}$ glucose solution. For the real blood tests, the bias was about $+3.6 \%$ comparing to the standard value from hospital in glucose sensing and the cell power was $25 \mu \mathrm{W} / \mathrm{cm}^{2}$ in biofuel cell at $25 \circ \mathrm{C}$.

Nowadays, most of diabetes check their glucose level by the commercial glucose test strips at home and inject insulin if they need. However, hemoglobin $\mathrm{A} 1 \mathrm{c}, \mathrm{Hb}_{\mathrm{A} 1 \mathrm{c}}$, recommended by the American Diabetes Association (ADA) provides an average blood glucose level during 60-90 days. It is a more accurate biomarker for long-term monitoring without external factors. In literatures, fructosyl valine (FV), which exists after protein digestion of $\mathrm{Hb}_{\mathrm{A} 1 \mathrm{c}}$, was 
monitored by enzyme-based electrochemical biosensor (Fang et al., 2009) or molecularimprinting biosensor (Chuang et al., 2009). The recent challenge in $\mathrm{Hb}_{\mathrm{A} 1 \mathrm{C}}$ part is still how to lower the interference signal, especially the effect of heme in our experiment. Heme also exists along with FV in sample after protein digestion, so this matter will be an issue for future study.

\section{Acknowledgement}

This work was partially sponsored by a grant received from the Ministry of Economics, Taiwan. Some instruments used in this study were supported by the National Research Council of Taiwan.

\section{References}

Akyilmaz, E. \& Yorganci, E. (2007). Construction of an amperometric pyruvate oxidase enzyme electrode for determination of pyruvate and phosphate. Electrochimica Acta, 52, 28, Nov 2007, 7972-7977.

Auroux, P.A.; Iossifidis, D.; Reyes, D.R. \& Manz, A. (2002). Micro total analysis systems. 2. Analytical standard operations and applications. Analytical Chemistry, 74, 12, Jun 2002, 2637-2652.

Bard, A.J.; Crayston, J.A.; Kittlesen, G.P.; Shea, T.V. \& Wrighton, M.S. (1986). Digitalsimulation of the measured electrochemical response of reversible redox couples at microelectrode arrays - consequences arising from closely spaced ultramicroelectrodes. Analytical Chemistry, 58, 11, Sep 1986, 2321-2331.

Battaglini, F.; Bartlett, P.N. \& Wang, J.H. (2000). Covalent attachment of osmium complexes to glucose oxidase and the application of the resulting modified enzyme in an enzyme switch responsive to glucose. Analytical Chemistry, 72, 3, Feb 2000, 502-509.

Battaglini, F.; Koutroumanis, M.; English, A.M. \& Mikkelsen, S.R. (1994). Targeting glucose oxidase at aspartate and glutamate residues with organic 2 electron redox mediators. Bioconjugate Chemistry, 5, 5, Sep 1994, 430-435.

Bogdanovskaya, V.A.; Kuznetsova, L.N. \& Tarasevich, M.R. (1997). Bioelectrocatalysis by immobilized peroxidase: The effects caused by the carbon black surface coverage with the enzyme and by the enzyme-Nafion composition on the activity in the hydrogen peroxide reduction. Russian Journal of Electrochemistry, 33, 10, Oct 1997, 1087-1091.

Boguslavsky, L.I.; Geng, L.; Kovalev, I.P.; Sahni, S.K.; Xu, Z. \& Skotheim, T.A. (1995). Amperometric thin-film biosensors based on glucose dehydrogenase and toluidineblue-o as catalyst for NADH electroxidation. Biosensors $\mathcal{E}$ Bioelectronics, 10, 8, Fal 1995, 693-704.

Borole, D.D.; Kapadi, U.R.; Mahulikar, P.P. \& Hundiwale, D.G. (2004). Glucose oxidase electrodes of polyaniline, poly(o-toluidine) and their copolymer as a biosensor: a comparative study. Polymers for Advanced Technologies, 15, 6, Jun 2004, 306-312.

Bourdillon, C.; Demaille, C.; Moiroux, J. \& Saveant, J.M. (1995). Catalysis and mass transport in spatially ordered enzyme assemblies on electrodes. Journal of the American Chemical Society, 117, 46, Nov 1995, 11499-11506.

Bourdillon, C.; Laval, J.M. \& Thomas, D. (1986). Enzymatic electrocatalysis - controlled potential electrolysis and cosubstrate regeneration with immobilized enzyme modified electrode. Journal of the Electrochemical Society, 133, 4, Apr 1986, 706-711. 
Brahim, S.; Narinesingh, D. \& Guiseppi-Elie, A. (2001). Amperometric determination of cholesterol in serum using a biosensor of cholesterol oxidase contained within a polypyrrole-hydrogel membrane. Analytica Chimica Acta, 448, 1-2, Dec 2001, 27-36.

Brunel, L.; Denele, J.; Servat, K.; Kokoh, K.B.; Jolivalt, C.; Innocent, C.; Cretin, M.; Rolland, M. \& Tingry, S. (2007). Oxygen transport through laccase biocathodes for a membrane-less glucose/O-2 biofuel cell. Electrochemistry Communications, 9, 2, Feb 2007, 331-336.

Cenas, N.K.; Pocius, A.K. \& Kulys, J.J. (1983). Electron exchange between flavin-containing and heme-containing enzymes and electrodes modified by redox polymers. Bioelectrochemistry and Bioenergetics, 11, 1, Jan 1983, 61-73.

Chaubey, A. \& Malhotra, B.D. (2002). Mediated biosensors. Biosensors \& Bioelectronics, 17, 67, Jun 2002, 441-456.

Chen, L.Q.; Zhang, X.E.; Xie, W.H.; Zhou, Y.F.; Zhang, Z.P. \& Cass, A.E.G. (2002). Genetic modification of glucose oxidase for improving performance of an amperometric glucose biosensor. Biosensors \& Bioelectronics, 17, 10, Oct 2002, 851-857.

Chen, P.-Y.; Vittal, R.; Nien, P.C. \& Ho, K.C. (2009). Enhancing dopamine detection using a glassy carbon electrode modified with MWCNTs, quercetin and Nafion. Biosensors $\mathcal{E}$ Bioelectronics, 24, May 2009, 3504-3509.

Chu, X.; Duan, D.X.; Shen, G.L. \& Yu, R.Q. (2007). Amperometric glucose biosensor based on electrodeposition of platinum nanoparticles onto covalently immobilized carbon nanotube electrode. Talanta, 71, 5, Mar 2007, 2040-2047.

Chuang, S.W.; Rick, J. \& Chou, T.C. (2009). Electrochemical characterisation of a conductive polymer molecularly imprinted with an Amadori compound. Biosensors $\mathcal{E}$ Bioelectronics, 24, 10, Jun 2009, 3170-3173.

Clark, L.C. \& Lyons, C. (1962). Electrode systems for continuous monitoring in cardiovascular surgery. Annals of the New York Academy of Sciences, 102, 1, Apr 1962, 29-33.

Cosnier, S. (1999). Biomolecule immobilization on electrode surfaces by entrapment or attachment to electrochemically polymerized films. A review. Biosensors $\mathcal{E}$ Bioelectronics, 14, 5, May 1999, 443-456.

Cosnier, S. (2003). Biosensors based on electropolymerized films: new trends. Analytical and Bioanalytical Chemistry, 377, 3, Oct 2003, 507-520.

Cosnier, S.; Lepellec, A.; Guidetti, B. \& Rico-Lattes, I. (1998). Enhancement of biosensor sensitivity in aqueous and organic solvents using a combination of poly(pyrroleammonium) and poly(pyrrole-lactobionamide) films as host matrices. Journal of Electroanalytical Chemistry, 449, 1-2, Jun 1998, 165-171.

Crespilho, F.N.; Ghica, M.E.; Gouveia-Caridade, C.; Oliveira, O.N. \& Brett, C.M.A. (2008). Enzyme immobilisation on electroactive nanostructured membranes (ENM): Optimised architectures for biosensing. Talanta, 76, 4, Aug 2008, 922-928.

Cunningham, A.J. (1998). Introduction to Bioanalytical Sensors, John Wiley \& Sons Inc., New York.

Dubinin, A.G.; Li, F.C.; Li, Y.R. \& Yu, J.T. (1991). A solid-state immobilized enzyme polymer membrane microelectrode for measuring lactate ion concentration. Bioelectrochemistry and Bioenergetics, 25, 1, Feb 1991, 131-135.

Duine, J.A.; Frank, J. \& Vanzeeland, J.K. (1979). Glucose dehydrogenase from acientobacter calcoaceticus quinoprotein. Febs Letters, 108, 2, Feb 1979, 443-446.

Ekanayake, E.; Preethichandra, D.M.G. \& Kaneto, K. (2007). Polypyrrole nanotube array sensor for enhanced adsorption of glucose oxidase in glucose biosensors. Biosensors E Bioelectronics, 23, 1, Aug 2007, 107-113.

Fabiano, S.; Tran-Minh, C.; Piro, B.; Dang, L.A.; Pham, M.C. \& Vittori, O. (2002). Poly 3,4ethylenedioxythiophene as an entrapment support for amperometric enzyme 
sensor. Materials Science \& Engineering C-Biomimetic and Supramolecular Systems, 21, 1-2, Sep 2002, 61-67.

Fang, L.; Li, W.; Zhou, Y. \& Liu, C.C. (2009). A single-use, disposable iridium-modified electrochemical biosensor for fructosyl valine for the glycoslated hemoglobin detection. Sensors and Actuators B-Chemical, 137, 1, Mar 2009, 235-238.

Fiaccabrino, G.C.; de Rooij, N.F. \& Koudelka-Hep, M. (1998). On-chip generation and detection of electrochemiluminescence. Analytica Chimica Acta, 359, 3, Feb 1998, 263-267.

Ford, S.M.; Kar, B.; McWhorter, S.; Davies, J.; Soper, S.A.; Klopf, M.; Calderon, G. \& Saile, V. (1998). Microcapillary electrophoresis devices fabricated using polymeric substrates and X-ray lithography. Journal of Microcolumn Separations, 10, 5, 1998, 413-422.

Franke, W. \& Deffner, M. (1939). On the knowledge of the so-called glucose oxidase II. Justus Liebigs Annalen Der Chemie, 541, Nov 1939, 117-150.

Gamati, S.; Luong, J.H.T. \& Mulchandani, A. (1991). A microbial biosensor for trimethylamine using pseudomonas-aminovorans cells. Biosensors $\mathcal{E}$ Bioelectronics, 6, 2, Feb 1991, 125-131.

Gilmartin, M.A.T. \& Hart, J.P. (1995). Development of one-shot biosensors for the measurement of uric acid and cholesterol. Analytical Proceedings, 32, 8, Aug 1995, 341-345.

Habermuller, K. \& Schuhmann, W. (1998). A low-volume electrochemical cell for the deposition of conducting polymers and entrapment of enzymes. Electroanalysis, 10, 18, Dec 1998, 1281-1284.

Habrioux, A.; Sibert, E.; Servat, K.; Vogel, W.; Kokoh, K.B. \& Alonso-Vante, N. (2007). Activity of platinum-gold alloys for glucose electrooxidation in biofuel cells. Journal of Physical Chemistry B, 111, 34, Aug 2007, 10329-10333.

Hamdi, N.; Wang, J.J.; Walker, E.; Maidment, N.T. \& Monbouquette, H.G. (2006). An electroenzymatic L-glutamate microbiosensor selective against dopamine. Journal of Electroanalytical Chemistry, 591, 1, Jun 2006, 33-40.

Hecht, H.J.; Kalisz, H.M.; Hendle, J.; Schmid, R.D. \& Schomburg, D. (1993). Crystal structure of glucose oxidase from aspergillus niger refined at 23 angstrom resolution. Journal of Molecular Biology, 229, 1, Jan 1993, 153-172.

Heller, A. \& Feldman, B. (2008). Electrochemical glucose sensors and their applications in diabetes management. Chemical Reviews, 108, 7, Jul 2008, 2482-2505.

Hendry, S.P.; Cardosi, M.F.; Turner, A.P.F. \& Neuse, E.W. (1993). Polyferrocenes as mediators in amperometric biosensors for glucose. Analytica Chimica Acta, 281, 3, Sep 1993, 453-459.

Himuro, Y.; Takai, M. \& Ishihara, K. (2009). Poly(vinylferrocene-co-2-hydroxyethyl methacrylate) mediator as immobilized enzyme membrane for the fabrication of amperometric glucose sensor. Sensors and Actuators B-Chemical, 136, 1, Feb 2009, 122-127.

Hosokawa, K. \& Maeda, R. (2000). A pneumatically-actuated three-way microvalve fabricated with polydimethylsiloxane using the membrane transfer technique. Journal of Micromechanics and Microengineering, 10, 3, Sep 2000, 415-420.

Huang, C.J.; Chen, Y.H.; Wang, C.H.; Chou, T.C. \& Lee, G.B. (2007). Integrated microfluidic systems for automatic glucose sensing and insulin injection. Sensors and Actuators BChemical, 122, 2, Mar 2007, 461-468.

Jaffari, S.A. \& Turner, A.P.F. (1997). Novel hexacyanoferrate(III) modified graphite disc electrodes and their application in enzyme electrodes. Biosensors $\mathcal{E}$ Bioelectronics, 12, 1, Mar 1997, 1-9.

Jia, W.Z.; Hu, Y.L.; Song, Y.Y.; Wang, K. \& Xia, X.H. (2008). Highly selective amperometric glucose microdevice derived from diffusion layer gap electrode. Biosensors $\mathcal{E}$ Bioelectronics, 23, 6, Jan 2008, 892-898. 
Jia, W.Z.; Wang, K.; Song, Y.Y. \& Xia, X.H. (2007). Diffusion layer based probe-in-tube microdevice for selective analysis of electroactive species. Electrochemistry Communications, 9, 7, Jul 2007, 1553-1557.

Karyakin, A.A.; Strakhova, A.K.; Karyakina, E.E.; Varfolomeyev, S.D. \& Yatsimirsky, A.K. (1993). The electrochemical polymerization of methylene blue and bioelectrochemical activity of the resulting film. Synthetic Metals, 60, 3, Oct 1993, 289-292.

Kohma, T.; Hasegawa, H.; Oyamatsu, D. \& Kuwabata, S. (2007). Utilization of AC impedance measurements for electrochemical glucose sensing using glucose oxidase to improve detection selectivity. Bulletin of the Chemical Society of Japan, 80, 1, Jan 2007, 158-165.

Kojima, A.; Hyon, C.K.; Kamimura, T.; Maeda, M. \& Matsumoto, K. (2005). Protein sensor using carbon nanotube field effect transistor. Japanese Journal of Applied Physics Part 1-Regular Papers Short Notes \& Review Papers, 44, 4A, Apr 2005, 1596-1598.

Krishnamoorthy, K.; Gokhale, R.S.; Contractor, A.Q. \& Kumar, A. (2004). Novel label-free DNA sensors based on poly(3,4-ethylenedioxythiophene). Chemical Communications, 7, Apr 2004, 820-821.

Kros, A.; Sommerdijk, N. \& Nolte, R.J.M. (2005). Poly(pyrrole) versus poly (3,4ethylenedioxythiophene): implications for biosensor applications. Sensors and Actuators B-Chemical, 106, 1, Apr 2005, 289-295.

Kulys, J.; Tetianec, L. \& Ziemys, A. (2006). Probing Aspergillus niger glucose oxidase with pentacyanoferrate(III) aza- and thia-complexes. Journal of Inorganic Biochemistry, 100, 10, Oct 2006, 1614-1622.

Kurita, R.; Hayashi, K.; Fan, X.; Yamamoto, K.; Kato, T. \& Niwa, O. (2002). Microfluidic device integrated with pre-reactor and dual enzyme-modified microelectrodes for monitoring in vivo glucose and lactate. Sensors and Actuators B-Chemical, 87, 2, Dec 2002, 296-303.

Lee, T.M.H.; Carles, M.C. \& Hsing, I.M. (2003). Microfabricated PCR-electrochemical device for simultaneous DNA amplification and detection. Lab on a Chip, 3, 2, Apr 2003, 100-105.

Lerch, K.; Jonas, F. \& Linke, M. (1998). Properties and applications of Baytron (PEDT). Journal De Chimie Physique Et De Physico-Chimie Biologique, 95, 6, Jun 1998, 1506-1509.

Lin, C.L.; Shih, C.L. \& Chau, L.K. (2007a). Amperometric L-Lactate sensor based on sol-gel processing of an enzyme-linked silicon alkoxide. Analytical Chemistry, 79, 10, May 2007a, 3757-3763.

Lin, T.Y.; Wu, C.H. \& Brennan, J.D. (2007b). Entrapment of horseradish peroxidase in sugarmodified silica monoliths: Toward the development of a biocatalytic sensor. Biosensors \& Bioelectronics, 22, 2007b, 1861-1867.

Liu, A.L.; Zhou, T.; He, F.Y.; Xu, J.J.; Lu, Y.; Chen, H.Y. \& Xia, X.H. (2006). Off-line form of the Michaelis-Menten equation for studying the reaction kinetics in a polymer microchip integrated with enzyme microreactor. Lab on a Chip, 6, 6, Jun 2006, 811-818.

Liu, Y. \& Dong, S.J. (2007a). A biofuel cell harvesting energy from glucose-air and fruit juiceair. Biosensors E Bioelectronics, 23, 4, Nov 2007a, 593-597.

Liu, Y. \& Dong, S.J. (2007b). A biofuel cell with enhanced power output by grape juice. Electrochemistry Communications, 9, 7, Jul 2007b, 1423-1427.

Liu, Y.J.; Ganser, D.; Schneider, A.; Liu, R.; Grodzinski, P. \& Kroutchinina, N. (2001). Microfabricated polycarbonate CE devices for DNA analysis. Analytical Chemistry, 73, 17, Sep 2001, 4196-4201.

Loonberg, M. \& Carlsson, J. (2006). Lab-on-a-chip technology for determination of protein isoform profiles. Journal of Chromatography A, 1127, 1-2, Sep 2006, 175-182. 
Luong, J.H.T.; Masson, C.; Brown, R.S.; Male, K.B. \& Nguyen, A.L. (1994). Monitoring the activity of glucose oxidase during the cultivation of aspergillus niger using novel amperometric sensor with 1,1'-dimethylferricinium as a mediator. Biosensors $\mathcal{E}$ Bioelectronics, 9, 8, Oct 1994, 577-584.

Mailley, P.; Cosnier, S. \& Coche-Guerente, L. (2000). Amperometric glucose biosensors based on composite polymeric structures to prevent interferences. Analytical Letters, 33, 9, Sep 2000, 1733-1753.

Malmstadt, H. \& Pardue, H.L. (1961). Quantitative analysis by an antomatic potentimetric reaction rate method - specific enzymatic determination of glucose. Analytical Chemistry, 33, 8, Aug 1961, 1040-1045.

Mano, N.; Mao, F. \& Heller, A. (2005). On the parameters affecting the characteristics of the "wired" glucose oxidase anode. Journal of Electroanalytical Chemistry, 574, 2, Jan 2005, 347-357.

Mao, F.; Mano, N. \& Heller, A. (2003). Long tethers binding redox centers to polymer backbones enhance electron transport in enzyme "wiring" hydrogels. Journal of the American Chemical Society, 125, 16, Apr 2003, 4951-4957.

Matuszewski, W.; Trojanowicz, M. \& Lewenstam, A. (1990). Elimination of interferences in flow-injection amperometric determination of glucose in blood-serum using immobilized glucose-oxidase. Electroanalysis, 2, 8, Nov 1990, 607-615.

McDonald, J.C.; Duffy, D.C.; Anderson, J.R.; Chiu, D.T.; Wu, H.K.; Schueller, O.J.A. \& Whitesides, G.M. (2000). Fabrication of microfluidic systems in poly(dimethylsiloxane). Electrophoresis, 21, 1, Jan 2000, 27-40.

Min, J.H. \& Baeumner, A.J. (2004). Characterization and optimization of interdigitated ultramicroelectrode arrays as electrochemical biosensor transducers. Electroanalysis, 16, 9, May 2004, 724-729.

Muller, U.; Nisch, W.; Pawlak, M.; Gierke, B.; Breisch, S.; Burkhardt, C.; Rudorf, R.; Neugebauer, S.; Schuhmann, W.; Linke, S.; Kaczor, M.; Lohmuller, T.; Spatz, J.; Motz, M.; Sorsa, J.; Hecke, S.; Hartwich, G. \& Stelzle, M. (2007). A novel nanoporous electrode system to enhance Biosensor sensitivity., Proceedings of NSTINanotech 2007, pp. 206-209, Santa Clara, May and 2007, Nano Science and Technology Institute.

Nakaminami, T.; Kuwabata, S. \& Yoneyama, H. (1997). Electrochemical oxidation of cholesterol catalyzed by cholesterol oxidase with use of an artificial electron mediator. Analytical Chemistry, 69, 13, Jul 1997, 2367-2372.

Navera, E.N.; Suzuki, M.; Tamiya, E.; Takeuchi, T. \& Karube, I. (1993). Nafion-coated carbonfiber for acetylcholine and choline sensors. Electroanalysis, 5, 1, Jan 1993, 17-22.

Ngounou, B.; Aliyev, E.H.; Guschin, D.A.; Sultanov, Y.M.; Efendiev, A.A. \& Schuhmann, W. (2007). Parallel synthesis of libraries of anodic and cathodic functionalized electrodeposition paints as immobilization matrix for amperometric biosensors. Bioelectrochemistry, 71, 1, Sep 2007, 81-90.

Nien, P.C.; Huang, M.C.; Chang, F.Y. \& Ho, K.C. (2008). Integrating an enzyme-entrapped conducting polymer electrode and a prereactor in a microfluidic system for sensing glucose. Electroanalysis, 20, 6, Mar 2008, 635-642. Copyright Wiley-VCH Verlag $\mathrm{GmbH} \& \mathrm{Co} . \mathrm{KGaA}$. Reproduced with permission.

Nien, P.C.; Tung, T.S. \& Ho, K.C. (2006). Amperometric glucose biosensor based on entrapment of glucose oxidase in a poly(3,4-ethylenedioxythiophene) film. Electroanalysis, 18, 13-14, Jul 2006, 1408-1415.

Nien, P.C.; Wang, J.Y.; Chen, P.Y.; Chen, L.C. \& Ho, K.C. (2009). Co-immobilization of benzoquinone and glucose oxidase in a PEDOT: Application to oxygen- 
independent glucose sensors and glucose $/ \mathrm{O}_{2}$ biofuel cells, submitted to Biosensors and Bioelectronics.

Palmisano, F.; Malitesta, C.; Centonze, D. \& Zambonin, P.G. (1995). Correlation between permselectivity and chemical structure of overoxidized polypyrrole membranes used in electroproduced enzyme biosensors. Analytical Chemistry, 67, 13, Jul 1995, 2207-2211.

Qiu, H.; Peng, H. \& Liang, R. (2007). Ferrocene-modified $\mathrm{Fe}_{3} \mathrm{O}_{4} @ \mathrm{SiO}_{2}$ magnetic nanoparticles as building blocks for construction of reagentless enzyme-based biosensors. Electrochemistry Communications, 9, 11, Nov 2007, 2734-2738.

Qiu, J.D.; Zhou, W.M.; Guo, J.; Wang, R. \& Liang, R.P. (2009). Amperometric sensor based on ferrocene-modified multiwalled carbon nanotube nanocomposites as electron mediator for the determination of glucose. Analytical Biochemistry, 385, 2, Feb 2009, 264-269.

Rahman, A.; Park, D.S. \& Shim, Y.B. (2004). A performance comparison of choline biosensors: anodic or cathodic detections of $\mathrm{H}_{2} \mathrm{O}_{2}$ generated by enzyme immobilized on a conducting polymer. Biosensors \& Bioelectronics, 19, 12, Jul 2004, 1565-1571.

Rao, J.R. \& Richter, G. (1974). Implantable bioelectrochemical power sources. Naturwissenschaften, 61, 5, May 1974, 200-206.

Rao, J.R.; Richter, G.; Sturm, F.V.; Weidlich, E. \& Wenzel, M. (1974). Metal-oxygen and glucoseoxygen cells for implantable devices. Biomedical Engineering, 9, 3, Mar 1974, 98-103.

Richter, T.; Shultz-Lockyear, L.L.; Oleschuk, R.D.; Bilitewski, U. \& Harrison, D.J. (2002). Bienzymatic and capillary electrophoretic analysis of non-fluorescent compounds in microfluidic devices - Determination of xanthine. Sensors and Actuators B-Chemical, 81, 2-3, Jan 2002, 369-376.

Schoning, M.J.; Jacobs, M.; Muck, A.; Knobbe, D.T.; Wang, J.; Chatrathi, M. \& Spillmann, S. (2005). Amperometric PDMS/glass capillary electrophoresis-based biosensor microchip for catechol and dopamine detection. Sensors and Actuators B-Chemical, 108, 1-2, Jul 2005, 688-694.

Sehr, P.; Zumbach, K. \& Pawlita, M. (2001). A generic capture ELISA for recombinant proteins fused to glutathione S-transferase: validation for HPV serology. Journal of Immunological Methods, 253, 1-2, Jul 2001, 153-162.

Selampinar, F.; Akbulut, U.; Ozden, M.Y. \& Toppare, L. (1997). Immobilization of invertase in conducting polymer matrices. Biomaterials, 18, 17, Sep 1997, 1163-1168.

Seo, K.D.; Lee, K.P.; Gopalan, A.I.; Chung, S.J.; Lim, Y.T. \& Choi, S.H. (2007). Horseradish peroxidase (HRP) immobilized poly(aniline-co-m-aminophenol) film electrodesfabrication and evaluation as hydrogen peroxide sensor. Sensors, 7, 5, May 2007, 719-729.

Setti, L.; Fraleoni-Morgera, A.; Ballarin, B.; Filippini, A.; Frascaro, D. \& Piana, C. (2005). An amperometric glucose biosensor prototype fabricated by thermal inkjet printing. Biosensors \& Bioelectronics, 20, 10, Apr 2005, 2019-2026.

Sheppard, N.F.; Mears, D.J. \& GuiseppiElie, A. (1996). Model of an immobilized enzyme conductimetric urea biosensor. Biosensors \& Bioelectronics, 11, 10, Dec 1996, 967-979.

Shulga, A.A.; Koudelkahep, M.; Derooij, N.F. \& Netchiporouk, L.I. (1994). Glucose-sensitive enzyme field-effect transistor using potassium ferricyanide as an oxidizing substrate. Analytical Chemistry, 66, 2, Jan 1994, 205-210.

Singh, S.; Chaubey, A. \& Malhotra, B.D. (2004). Amperometric cholesterol biosensor based on immobilized cholesterol esterase and cholesterol oxidase on conducting polypyrrole films. Analytica Chimica Acta, 502, 2, Jan 2004, 229-234. 
Tamiya, E.; Sugiura, Y.; Akiyama, A. \& Karube, I. (1990). Ultramicro- $\mathrm{H}_{2} \mathrm{O}_{2}$ electrode for fabrication of the invivo biosensor. Annals of the New York Academy of Sciences, 613, Dec 1990, 396-400.

Tian, F.M. \& Zhu, G.Y. (2002). Bienzymatic amperometric biosensor for glucose based on polypyrrole/ceramic carbon as electrode material. Analytica Chimica Acta, 451, 2, Jan 2002, 251-258.

Trojanowicz, M.; Geschke, O.; Krawczyk, T.K.V. \& Cammann, K. (1995). Biosensors based on oxidases immobilized in various conducting polymers. Sensors and Actuators BChemical, 28, 3, Sep 1995, 191-199.

Tsujimura, S.; Kojima, S.; Kano, K.; Ikeda, T.; Sato, M.; Sanada, H. \& Omura, H. (2006). Novel FAD-dependent glucose dehydrogenase for a dioxygen-insensitive glucose biosensor. Bioscience Biotechnology and Biochemistry, 70, 3, Mar 2006, 654-659.

Unger, M.A.; Chou, H.P.; Thorsen, T.; Scherer, A. \& Quake, S.R. (2000). Monolithic microfabricated valves and pumps by multilayer soft lithography. Science, 288, 5463, Apr 2000, 113-116.

Vasantha, V.S. \& Chen, S.M. (2006). Electrocatalysis and simultaneous detection of dopamine and ascorbic acid using poly(3,4-ethylenedioxy)thiophene film modified electrodes. Journal of Electroanalytical Chemistry, 592, 1, Jul 2006, 77-87.

Vedrine, C.; Fabiano, S. \& Tran-Minh, C. (2003). Amperometric tyrosinase based biosensor using an electrogenerated polythiophene film as an entrapment support. Talanta, 59, 3, Mar 2003, 535-544.

Vidal, J.C.; Garcia-Ruiz, E. \& Castillo, J.R. (2001). Design of a multilayer cholesterol amperometric biosensor for preparation and use in flow systems. Electroanalysis, 13, 3, Mar 2001, 229-235.

Wang, Z.G.; Wano, Y.; Xu, H.; Li, G. \& Xu, Z.K. (2009). Carbon Nanotube-Filled Nanofibrous Membranes Electrospun from Poly(acrylonitrile-co-acrylic acid) for Glucose Biosensor. Journal of Physical Chemistry C, 113, 7, Feb 2009, 2955-2960.

Warburg, O. \& Christian, W. (1932). On a new oxidation enzyme and its absorption spectrum. Biochemische Zeitschrift, 254, Jul 1932, 438-458.

Williams, D.L.; Doig, A.R. \& Korosi, A. (1970). Electrochemical-enzymatic analysis of blood glucose and lactate. Analytical Chemistry, 42, 1, Jan 1970, 118-123.

Willner, I.; Baron, R. \& Willner, B. (2007a). Integrated nanoparticle-biomolecule systems for biosensing and bioelectronics. Biosensors $\mathcal{E}$ Bioelectronics, 22, 9-10, Apr 2007a, 1841-1852.

Willner, I.; Willner, B. \& Katz, E. (2007b). Biomolecule-nanoparticle hybrid systems for bioelectronic applications. Bioelectrochemistry, 70, 1, Jan 2007b, 2-11.

Wu, F.H.; Zhao, G.C. \& Wei, X.W. (2002). Electrocatalytic oxidation of nitric oxide at multiwalled carbon nanotubes modified electrode. Electrochemistry Communications, 4, 9, Sep 2002, 690-694.

Wu, X.M.; Du, P.; Wu, P. \& Cai, C.X. (2008). Effects of 1-butyl-3-methylimidazolium tetrafluoroborate on the oxidation of glucose catalyzed by glucose oxidase. Electrochimica Acta, 54, 2, Dec 2008, 738-743.

Xie, J.; Miao, Y.N.; Shih, J.; Tai, Y.C. \& Lee, T.D. (2005). Microfluidic platform for liquid chromatography-tandem mass spectrometry analyses of complex peptide mixtures. Analytical Chemistry, 77, 21, Nov 2005, 6947-6953.

Yamaguchi, A.; Jin, P.; Tsuchiyama, H.; Masuda, T.; Sun, K.; Matsuo, S. \& Misawa, H. (2002). Rapid fabrication of electrochemical enzyme sensor chip using polydimethylsiloxane microfluidic channel. Analytica Chimica Acta, 468, 1, Sep 2002, 143-152. 
Yamato, H.; Ohwa, M. \& Wernet, W. (1995). Stability of polypyrrole and poly(3,4ethylenedioxythiophene) for biosensor application. Journal of Electroanalytical Chemistry, 397, 1-2, Nov 1995, 163-170.

Yan, Y.M.; Su, L. \& Mao, L.Q. (2007). Multi-walled carbon nanotube-based glucose/ $\mathrm{O}_{2}$ biofuel cell with glucose oxidase and laccase as biocatalysts. Journal of Nanoscience and Nanotechnology, 7, 4-5, Apr-May 2007, 1625-1630.

Yang, X.H.; Hall, S.B. \& Tan, S.N. (2003). Electrochemical reduction of a conjugated cinnamic acid diazonium salt as an immobilization matrix for glucose biosensor. Electroanalysis, 15, 10, Jul 2003, 885-891.

Yuan, J.H.; Wang, K. \& Xia, X.H. (2005). Highly ordered platinum-nanotubule arrays for amperometric glucose sensing. Advanced Functional Materials, 15, 5, May 2005, 803809.

Zakeeruddin, S.M.; Fraser, D.M.; Nazeeruddin, M.K. \& Gratzel, M. (1992). Towards mediator design - characterization of tris-(4,4'-substituted-2,2'-bipyridine) complexes of iron(II), ruthenium(II) and osmium(II) as mediators for glucose oxidase of aspergillusniger and other redox proteins. Journal of Electroanalytical Chemistry, 337, 1-2, Oct 1992, 253-283.

Zayats, M.; Willner, B. \& Willner, I. (2008). Design of amperometric biosensors and biofuel cells by the reconstitution of electrically contacted enzyme electrodes. Electroanalysis, 20, 6, Mar 2008, 583-601.

Zhang, Q.; Xu, J.J. \& Chen, H.Y. (2006a). Glucose microfluidic biosensors based on immobilizing glucose oxidase in poly(dimethylsiloxane) electrophoretic microchips. Journal of Chromatography A, 1135, 1, Nov 2006a, 122-126.

Zhang, S.X.; Wang, N.; Niu, Y.M. \& Sun, C.Q. (2005). Immobilization of glucose oxidase on gold nanoparticles modified Au electrode for the construction of biosensor. Sensors and Actuators B-Chemical, 109, 2, Sep 2005, 367-374.

Zhang, S.X.; Yang, W.W.; Niu, Y.M.; Li, Y.C.; Zhang, M. \& Sun, C.Q. (2006b). Construction of glucose biosensor based on sorption of glucose oxidase onto multilayers of polyelectrolyte/nanoparticles. Analytical and Bioanalytical Chemistry, 384, 3, Feb 2006b, 736-741.

Zhang, Y.N.; Hu, Y.B.; Wilson, G.S.; Moattisirat, D.; Poitout, V. \& Reach, G. (1994). Elimination of the acetaminophen interference in an implantable glucose sensor. Analytical Chemistry, 66, 7, Apr 1994, 1183-1188.

Zhao, C. \& Wittstock, G. (2005). Scanning electrochemical microscopy for detection of biosensor and biochip surfaces with immobilized pyrroloquinoline quinone (PQQ)dependent glucose dehydrogenase as enzyme label. Biosensors \& Bioelectronics, 20, 7, Jan 2005, 1277-1284.

Zhujun, Z. \& Seitz, W.R. (1986). Optical sensor for oxygen based on immobilized hemoglobin. Analytical Chemistry, 58, 1, Jan 1986, 220-222. 


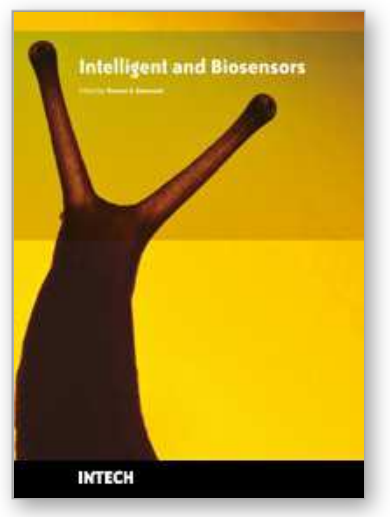

\author{
Intelligent and Biosensors \\ Edited by Vernon S. Somerset
}

ISBN 978-953-7619-58-9

Hard cover, 386 pages

Publisher InTech

Published online 01, January, 2010

Published in print edition January, 2010

The use of intelligent sensors have revolutionized the way in which we gather data from the world around us, how we extract useful information from that data, and the manner in which we use the newly obtained information for various operations and decision making. This book is an attempt to highlight the current research in the field of Intelligent and Biosensors, thereby describing state-of-the-art techniques in the field and emerging new technologies, also showcasing some examples and applications.

\title{
How to reference
}

In order to correctly reference this scholarly work, feel free to copy and paste the following:

Po-Chin Nien, Po-Yen Chen and Kuo-Chuan Ho (2010). Amperometric Enzyme-based Biosensors for Lowering the Interferences, Intelligent and Biosensors, Vernon S. Somerset (Ed.), ISBN: 978-953-7619-58-9, InTech, Available from: http://www.intechopen.com/books/intelligent-and-biosensors/amperometric-enzymebased-biosensors-for-lowering-the-interferences

\section{INTECH}

open science | open minds

\author{
InTech Europe \\ University Campus STeP Ri \\ Slavka Krautzeka 83/A \\ 51000 Rijeka, Croatia \\ Phone: +385 (51) 770447 \\ Fax: +385 (51) 686166 \\ www.intechopen.com
}

\author{
InTech China \\ Unit 405, Office Block, Hotel Equatorial Shanghai \\ No.65, Yan An Road (West), Shanghai, 200040, China \\ 中国上海市延安西路65号上海国际贵都大饭店办公楼 405 单元 \\ Phone: +86-21-62489820 \\ Fax: $+86-21-62489821$
}


(C) 2010 The Author(s). Licensee IntechOpen. This chapter is distributed under the terms of the Creative Commons Attribution-NonCommercialShareAlike-3.0 License, which permits use, distribution and reproduction for non-commercial purposes, provided the original is properly cited and derivative works building on this content are distributed under the same license. 